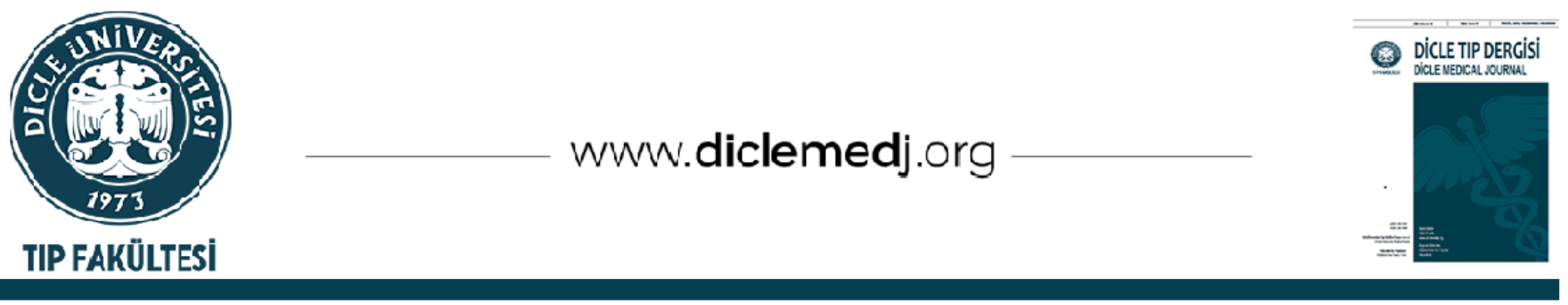

Original Article / Özgün Araştırma

\title{
The Importance of MPV as a Marker of Subclinical Inflammation in FMF Patients and It's Correlation with Disease Severity
}

\author{
Mesut Çeliker ${ }^{D_{1}}$, Sinan Kazan ${ }^{D_{2}}$, Onur Tunca ${ }^{i D_{2}}$, Alper Sarı ${ }^{D_{3}}$, Mustafa Köroğlu ${ }^{D_{4}}$, \\ Mennune Sena Ulu ${ }^{D_{2}}$ \\ 1 Ahi Evran University Kırșehir Training and Research Hospital, Internal Medicine Clinic Kırșehir, Turkey \\ 2 Afyonkarahisar Health Sciences University Hospital, Nephrology Department Afyonkarahisar, Turkey \\ 3 Afyonkarahisar Health Sciences University Hospital, Internal Medicine Department Afyonkarahisar, Turkey \\ 4 Istanbul Atlas University Hematology Department İstanbul, Turkey
}

Received: 23.02.2021; Revised: 06.08.2021; Accepted: 18.08.2021

\begin{abstract}
Objective: Inflammation markers increase during Familial Mediterranean Fever (FMF) attacks and often return to normal within a few days. It is known that a subclinical inflammation continues in FMF patients in the inter-episode period, which increases the risk of developing amyloidosis. In recent years, several works have been conducted showing the relationship between platelet indices and inflammation, such as platelet count (PLT), platelet distribution width (PDW), mean platelet volume (MPV), plateletrite (PCT). In this study, we aimed to investigate the relationship between platelet indices and disease severity in FMF patients without attacks.

Method: The records of all FMF patients followed by us were reviewed retrospectively. Patients with a hematological or oncological disease, patients with data deficiency for the study, and patients under 18 years of age were excluded. While the laboratory data were recorded, the condition of patients to be at least 3 months without attack was required. As the control group, the automation records of all healthcare professionals working in the internal medicine clinic of our hospital were examined. Our clinical staff, who did not have chronic diseases and regular drug use, were taken as a healthy control group. 173 patients and 20 control groups who met the conditions mentioned above were included in the study. Platelet indices were compared between patient and control groups.

Results: It was determined that the value of MPV, one of the platelet indices, in the patient group was statistically significantly higher than the value in the healthy control group ( $p=0.029$ ). MPV was also found to correlate with disease severity ( $p<0.001 \mathrm{r}=0.329$ ).

Discussion-Conclusion: In our study, it was determined that MPV was higher in FMF patients in the subclinical period compared to healthy controls and also correlated with disease severity. Studies investigating platelet indices and the risk of developing amyloidosis are needed in FMF patients.
\end{abstract}

Keywords: Familial Mediterranean Fever, Mean Platelet Volume, Subclinical inflammation

\section{DOI: 10.5798/dicletip.987759}

Correspondence / Yazıșma Adresi: Mesut Çeliker, Ahi Evran University Kırşehir Training and Research Hospital, Internal Medicine Clinic Kırşehir, Turkey e-mail: mesut_celiker@hotmail.com 


\section{MPV'nin FMF Hastalarında Subklinik İnflamasyon Belirteci Olarak Önemi ve Hastalık Şiddeti ile Korelasyonu}

Öz

Giriş: Ailesel Akdeniz Ateşi (FMF) atakları anında inflamasyon belirteçleri artış göstermekte ve çoğu zaman birkaç gün içerisinde normale dönmektedir. Ataklar arası dönemde de FMF hastalarında subklinik bir inflamasyonun devam ettiği ve bunun da amiloidoz gelişme riskini artırdığı bilinmektedir. Son yıllarda, trombosit sayısı (PLT), trombosit dağılım genişliği (PDW), ortalama trombosit hacmi (MPV), plateletkrit (PCT) gibi trombosit indeksleri ile inflamasyon arasındaki ilişkiyi gösteren birçok çalışma yapılmıştır. Bu çalışmamızda ataksız dönemdeki FMF hastalarında trombosit indeksleri ile hastalık şiddeti arasındaki ilişkiyi araştırmayı amaçladık.

Yöntemler: Kliniğimizce takip edilen tüm FMF hastalarının dosyaları retrospektif tarandı. Hematolojik veya onkolojik bir hastalığa sahip olanlar, çalışma için veri eksikliği olan hastalar ve 18 yaşından küçük hastalar çalışmaya alınmadı. Laboratuvar verileri kayıt altına alınırken hastaların en az 3 aylık ataksız dönemde olmaları koşulu arandı. Kontrol grubu olarak hastanemiz iç hastalıkları kliniğinde çalışan tüm sağlık çalışanlarının otomasyon kayıtları incelendi. Kronik hastalık ve düzenli ilaç kullanımı olmayan klinik çalışanlarımız sağlıklı kontrol grubu olarak alındı. Yukarıda belirtilen koşulları sağlayan 173 hasta ve 20 kontrol grubu çalışmaya dahil edildi. Hasta ve kontrol grupları arasında trombosit indeksleri karşılaștırıldı.

Bulgular: Trombosit indekslerinden MPV'nin hasta grubundaki değeri sağlıklı kontrol grubundaki değerine göre istatiksel olarak anlamlı derecede yüksek bulunduğu tespit edildi $(\mathrm{p}=0,029)$. MPV'nin aynı zamanda hastalık şiddeti ile de korelasyon gösterdiği tespit edildi ( $\mathrm{p}<0,001 \mathrm{r}=0,329)$.

Tartışma-Sonuç: Çalıșmamızda MPV'nin subklinik dönemde FMF hastalarında sağlıklı kontrollere göre yüksek olduğu ve aynı zamanda hastalık şiddeti ile de korelasyon gösterdiği saptanmıştır. FMF hastalarında trombosit indeksleri ve amiloidoz gelişim riskini araştıran çalışmalara ihtiyaç vardır.

Anahtar kelimeler: Ailevi Akdeniz Ateşi, Ortalama Trombosit Hacmi, Subklinik inflamasyon.

\section{INTRODUCTION}

Familial Mediterranean Fever (FMF) is a hereditary autoinflammatory disease with serosal inflammation characterized by recurrent episodes of fever ${ }^{1}$. The disease was first described by Janeway and Rosenthal in 1908 as "unusual recurrent peritonitis" in a 16year-old Jewish girl with recurrent fever, abdominal pain, and leukocytosis ${ }^{2}$. In Turkey, the first adult FMF patient the name 'Strange Abdominal Pain Syndrome' was diagnosed by Abrevaya Marmarall, in $1946^{3}$. The gene associated with the disease is the MediterraneanFeVer (MEFV) gene on the short arm of the 16th chromosome ${ }^{4}$. The presence of two pathogenic mutations in the MEFV gene confirms the diagnosis, on the other hand mutation was detected in only one third of FMF cases diagnosed clinically, 6 .

During FMF attacks, many acute phase reactants such as C-reactive protein, serum amyloid A, fibrinogen, and sedimentation increase ${ }^{7}$. It is known that a subclinical inflammation continues in FMF patients during the interattack period and this increases the risk of developing amyloidosis ${ }^{8-10}$. It has been shown that serum amyloid A levels are high in FMF patients even during in the attack-free period and can predict attacks ${ }^{11}$. Although, in some clinics in our country serum amyloid A level is used as an indicator of subclinical inflammation and adjustment of colchicine dose, it has not found a comprehensive place in the routine evaluation of FMF patients. In the last few years, several works have shown the relationship between platelet indices, platelet count (PLT), mean platelet volume (MPV), platelet distribution width (PDW), and plateletcrit (PCT) and inflammation ${ }^{12-17}$. In this study, we aimed to investigate the relationship between platelet indices and disease severity in FMF patients between attacks.

\section{METHOD}

\section{Patients and Control Group}

For the study, all FMF patients data who were followed up and treated in our hospital's 
Internal Medicine and Nephrology policlinic between May 2018 and May 2019 were retrospectively reviewed. All patients whose data could be accessed through the hospital automation system and gave consent for the study were incorporate into the study. As exclusion criteria from the study, the presence of a history of hematological disease that may affect the platelet indices, having an oncological disease, lack of data and being younger than 18 years were determined. FMF-related disease information and laboratory values of the patients were recorded. While the laboratory data were being recorded, the criteria was determined as the patients were in a period of at least 3 months without attacks. A detailed history of all patients were recorded and systemic physical examination was performed for all patients. Information of the FMF clinic was obtained through face-to-face interviews and detailed inquiries made with the patients by the same physician. Laboratory values were recorded with using the hospital automation system.

As the control group, the automation records of all healthcare professionals working in our hospital's internal medicine clinic were examined. Clinical staff with no chronic diseases and regular medication use were taken as a healthy control group. 173 patients and 20 control groups who met the conditions mentioned above were included in the study. Platelet indices were compared between the patient and control groups.

\section{Laboratory Measurements}

For the study, blood count and biochemical measurements obtained in the routine controls of the patients were used. Complete blood count was studied with Mindray BC-6800 hematology analyzer, biochemical parameters were performed on Cobas 8000 c 702 series biochemistry autoanalyzer and genetic analysis was performed with Roche 454 pyrosequencing method.

\section{Assessment of Disease Severity}

The Pras scoring system was used for disease severity (Table I) ${ }^{18}$. The patients were divided into 3 categories by summing their scores according to the scoring system. Patients with a total score $\leq 5$ were categorized as mild FMF, patients with 6-8 as moderate disease, and patients with $\geq 9$ as severe FMF.

Table I: Pras Severity Scoring

\begin{tabular}{|lll|} 
Parameter & Specifications & Score \\
\hline \multirow{3}{*}{ Age of onset } & $>31$ & 0 \\
& $21-31$ & 1 \\
& $11-20$ & 2 \\
& $6-10$ & 3 \\
Attacks per month & $<6$ & 4 \\
& $<1$ & 1 \\
\hline \multirow{2}{*}{ Arthritis } & $1-2$ & 2 \\
& $>2$ & 3 \\
\hline Erysipelas Like Erythema & Acute & 2 \\
\hline Amyloidosis & Chronic & 3 \\
\hline & & 2 \\
\hline \multirow{2}{*}{ Colchicine Dosage (mg/day) } & 1,5 & 3 \\
\hline & 2 & 1 \\
& $>2$ & 2 \\
\hline
\end{tabular}

\section{Statistical Analysis}

The data were analyzed by IBM SPSS Statistics22. 0 (IBM Corp. NY, USA) package program. Categorical variables were presented with percentages and frequencies. Chi-square test was used for comparison of categorical data. The compliance of continuous variables to normal distribution was checked with Shapiro Wilk and Kolmogorov-Smirnov tests. Student's t test was used for parameters showing normal range in comparison of patient and control groups, and Mann-Whitney U test was used for parameters that did not show normal range. ROC analysis was also performed for the MPV 
value, which was different from each other between the patient and control groups. While investigating the relationship between disease severity and platelet indices, normally distributed parameters were compared with the Oneway ANOVA test, and parameters not normally distributed were compared with the Kruskal-Wallis test. The pairwise comparison (Kruskal-Wallis) test was used as a post-hoc analysis for the MPV value with statistically significant difference between the groups. All $p$ values presented in the study are bidirectional and values with $\leq 0.05$ were considered statistically significant.

\section{RESULTS}

In this work $61.8 \%(\mathrm{n}=107)$ of our patients were female and $38.2 \%(n=66)$ were male. The median age of the patient group was 37 (range: 18-72) years. Control group includes $55 \%$ ( $\mathrm{n}=$ 11) female and $45 \%(n=9)$ male. The median age of the control group was 31 (range: 26-44) years. The patient and control groups were found to be similar in terms of gender and age ( $p=0.156$ and $\mathrm{p}=0.08$, respectively). When the platelet indices of the patient and control groups were compared, only MPV value was found to be statistically significantly higher in the patient group compared to healthy controls $(p=0.029)$ (Table II).

Table II: Comparison of Platelet Indexes of Patient and Control Groups

\begin{tabular}{|c|c|c|c|}
\hline Parameter & Patient & Control & $\mathbf{p}$ \\
\hline $\begin{array}{ll}\text { PLT } & \mathbf{( 1 0}^{3} \\
/ \mathrm{uL}) & \end{array}$ & $264,71 \pm 73,2$ & $257,25 \pm 62,3$ & 0,627 \\
\hline PDW(fL) & $14,28 \pm 2,6$ & $14,58 \pm 2,4$ & 0,936 \\
\hline MPV(fL) & $9,51 \pm 1,3$ & $8,87 \pm 0,7$ & 0,029 \\
\hline РСТ(\%) & $0,261 \pm 0,07$ & $0,252 \pm 0,05$ & 0,564 \\
\hline
\end{tabular}

PLT: Platelet PDW: Platelet Distribution Width MPV: Mean Platelet Volume PCT: Plateletcrit
In the ROC analysis, it was determined that MPV can be used for the separation of patient and control groups with $65.9 \%$ sensitivity and $65 \%$ specificity for $9.05 \mathrm{fl}$ value (AUC: $0.649 \mathrm{p}=$ $0.029 \% 95 \mathrm{CI}=0.556-0.742$ ). Figure 1 shows the ROC analysis for MPV.

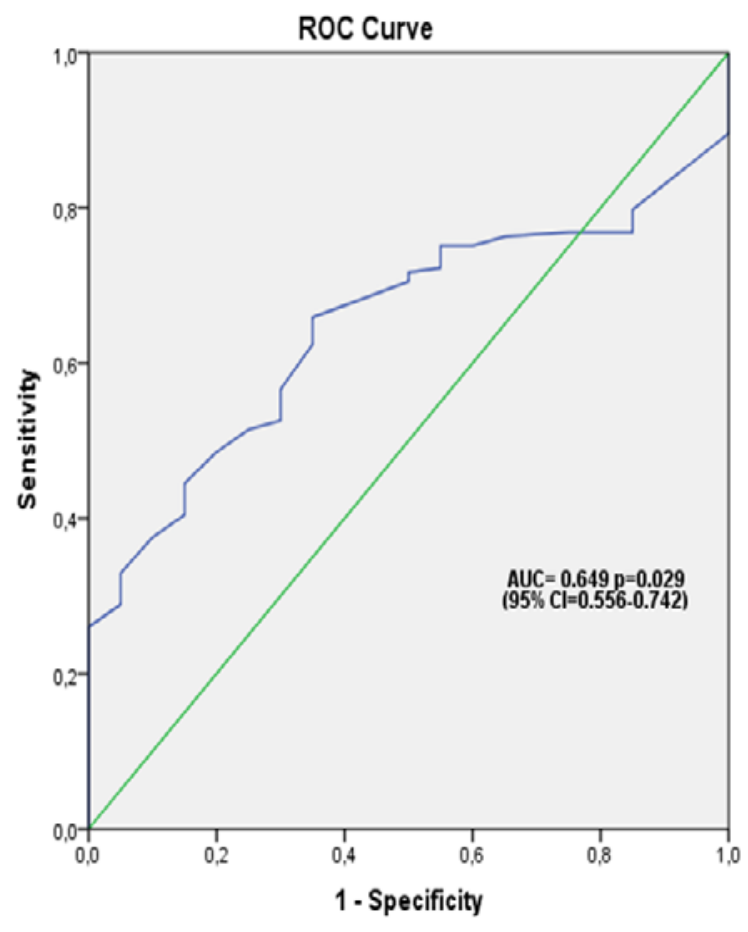

Figure 1. ROC analysis for MPV in differentiation of patient and control groups

The clinical and genetic features of FMF patients are summarized in Table III. The median Pras score of the patients was calculated as 5 (range: 2-12). According to the Pras severity score, $63.6 \%(n=110)$ of the patients were in the mild FMF group, $31.8 \%(n=55)$ in the moderate FMF, and $4.6 \%(n=8)$ in the severe FMF group. MPV values according to disease severity are shown in Figure 2. Also Posthoc analysis results for MPV are shown in Table $\mathrm{V}$. 
Table III: Clinical and Genetic characteristics of FMF patients

\begin{tabular}{|lll|} 
Parameter & $\begin{array}{l}\text { Number } \\
\text { (n) }\end{array}$ & Percent(\%) \\
\hline Abdominal Pain & & \\
Yes & 137 & 79,2 \\
No & 36 & 20,8 \\
\hline Erysipelas Like Erythema & & \\
Yes & 31 & 17,9 \\
No & 142 & 82,1 \\
\hline Relapsing fever & & \\
Yes & 128 & 74 \\
No & 45 & 26 \\
\hline Arthritis & & \\
Yes & 55 & 68,2 \\
No & 118 & 31,8 \\
\hline Family Yes & 128 & 74 \\
No & 45 & 26 \\
\hline Response to Colchicine & & \\
Yes & 163 & 94,2 \\
No & 10 & 5,8 \\
\hline Colchicine Dosage (mg/day) & & \\
1 & 88 & 50,8 \\
1,5 & 72 & 41,6 \\
2 & 11 & 6,4 \\
\hline$>2$ & 25,2 \\
\hline Mutation & 35 \\
Homozygous & & 16,8 \\
Compound heterozygous & 35 \\
Heterozygous & & 20,2 \\
Wild-type & & 28,3 \\
Unchecked & & 14,5 \\
\hline
\end{tabular}

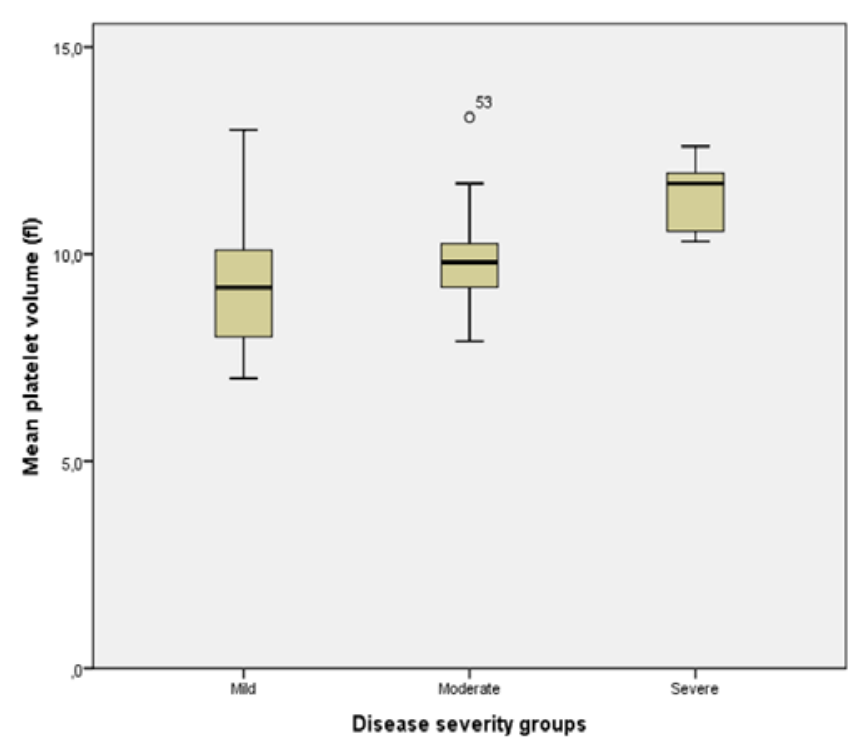

Figure 2. Comparison of MPV values according to disease severity

Table IV: Comparison of laboratory characteristics of patients according to the severity of FMF

\begin{tabular}{|c|c|c|c|c|}
\hline Parameter & $\begin{array}{l}\text { Mild } \\
\text { FMF }\end{array}$ & $\begin{array}{l}\text { Moderate } \\
\text { FMF }\end{array}$ & $\begin{array}{l}\text { Severe } \\
\text { FMF }\end{array}$ & $\mathbf{p}$ \\
\hline Urea(mg/dL) & $27,76 \pm 9,3$ & $31,72 \pm 23,1$ & $25,28 \pm 23,7$ & 0,495 \\
\hline Creatinine (mg/dL) & $0,79 \pm 0,3$ & $1,12 \pm 1,4$ & $0,92 \pm 0,6$ & 0,961 \\
\hline Sodium (mmol/L) & $140,41 \pm 2,4$ & $139,97 \pm 2,5$ & $140,2 \pm 0,8$ & 0,260 \\
\hline Potassium (mmol/L) & $4,46 \pm 0,3$ & $4,49 \pm 0,4$ & $4,4 \pm 0,2$ & 0,103 \\
\hline Glucose (mg/dL) & $95,52 \pm 16,2$ & $89,92 \pm 13,6$ & $88,02 \pm 6,7$ & 0,16 \\
\hline $\operatorname{AST}(\mathrm{U} / \mathrm{L})$ & $22,65 \pm 9,6$ & $20,14 \pm 9,2$ & $17,52 \pm 5,9$ & 0,126 \\
\hline ALT(U/L) & $24,27 \pm 16,7$ & $18,99 \pm 10,1$ & $16,76 \pm 11,1$ & 0,209 \\
\hline $\begin{array}{l}\text { Sedimentation(mm/ } \\
\text { s) }\end{array}$ & $13,28 \pm 7,2$ & $13,94 \pm 7,1$ & $8,2 \pm 4,3$ & 0,555 \\
\hline CRP(mg/dL) & $0,571 \pm 0,5$ & $0,468 \pm 0,4$ & $0,392 \pm 0,3$ & 0,612 \\
\hline Leukocyte $\left(10^{3} / \mathrm{uL}\right)$ & $6927 \pm 1744$ & $7522 \pm 1851$ & $8996 \pm 3106$ & 0,035 \\
\hline Neutrophil $\left(10^{3} / \mathrm{uL}\right)$ & $4005 \pm 1352$ & $4832 \pm 1793$ & $5960 \pm 2278$ & 0,002 \\
\hline $\begin{array}{l}\text { Lymphocyte } \\
\left(10^{3} / \mathrm{uL}\right)\end{array}$ & $2215 \pm 701$ & $1757 \pm 662$ & $2242 \pm 1084$ & 0,740 \\
\hline Hemoglobin (g/dL) & $14,15 \pm 1,8$ & $13,93 \pm 2,04$ & $14,5 \pm 2,2$ & 0,715 \\
\hline PLT $\left(10^{3} / \mathrm{uL}\right)$ & $258,4 \pm 73,3$ & $272,4 \pm 75,9$ & $274,6 \pm 65,8$ & 0,582 \\
\hline PDW (fL) & $13,93 \pm 2,5$ & $14,14 \pm 3,1$ & $13,7 \pm 2,8$ & 0,874 \\
\hline MPV (fL) & $9,23 \pm 1,3$ & $9,82 \pm 1,1$ & $11,72 \pm 0,7$ & $<0,001$ \\
\hline РCT (\%) & $0,258 \pm 0,07$ & $0,262 \pm 0,07$ & $0,284 \pm 0,05$ & 0,366 \\
\hline
\end{tabular}


Table V: Posthoc analysis results for MPV

\begin{tabular}{|lll|}
\hline Groups & Standard error & $\mathbf{p}$ \\
\hline Mild FMF- Moderate FMF & 8,264 & $\mathbf{0 , 0 1 2}$ \\
\hline Mild FMF-Severe FMF & 18,323 & $<\mathbf{0 , 0 0 1}$ \\
\hline Moderate FMF-Severe FMF & 18,934 & $\mathbf{0 , 0 0 9}$ \\
\hline
\end{tabular}

In addition, the comparison of the laboratory features of the patients according to the severity of FMF is shown in Table IV. When the correlation between MPV and the total scores obtained from Pras scoring was investigated, it was found that the Pras score showed a statistically significant but weak correlation with MPV ( $p<0.001 r=0.329)$. Figure 3 shows the correlation between Pras score and MPV.

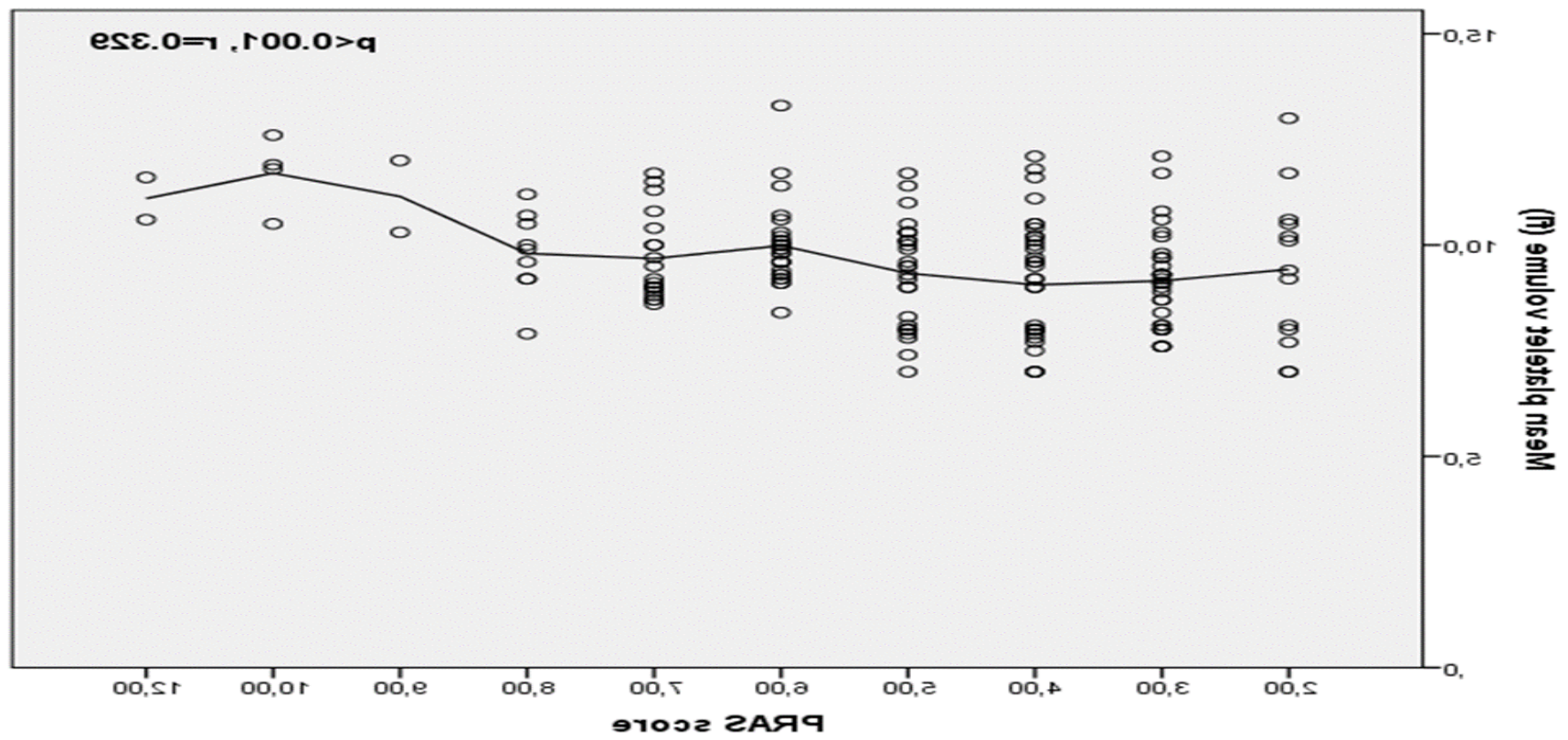

Figure 3. Correlation between Pras score and MPV

\section{DISCUSSION}

Unlike other inflammatory diseases, FMF patients clinically return to normal during the inter-attack periods. However, studies show that although the clinic is normal, a subclinical inflammation continues in the interval between attacks. Musabak et al. detected abnormal T cell activation in patients with FMF both during the attack period and during remission ${ }^{19}$. Bağcl et al. observed that IL-6, which is known to stimulate hepatic acute phase proteins, rises suddenly during attacks and remains high during remission ${ }^{20}$. Erken et al. found that IL-12 levels in FMF patients were higher than healthy controls, regardless of the attacks ${ }^{21}$. A similar study was conducted by Şimşek et al. in patients with FMF, serum IL-12 and IL-18 levels were found to be high during attack and during attack-free period; stated that increased IL-12 and IL-18 levels in the remission period showed Th1 activation and that a subclinical inflammation continued in the period without attacks ${ }^{22}$. However, none of the inflammatory markers evaluated in the studies performed are the parameters that are in routine use especially for developing countries such as our country and may be in the near future. Therefore, there is a need for an inflammation marker that can indicate subclinical inflammation in FMF patients and may be related to disease severity. MPV as the part of platelet indices; it has been used as a marker in many studies, especially in inflammation, due to the fact that the platelets that come into the environment in case of inflammation are young and large in volume. 
The results of studies investigating MPV in FMF patients in the literature are quite heterogeneous. Çoban and Adanır found MPV to be high when comparing FMF patients in the attack-free period with the control group ${ }^{23}$. Abanönü et al. examined the relationship between the use of colchicine and MPV in patients with FMF, and compared the patients with FMF in the attack-free period with the control group, and they found that MPV values did not create a statistical difference between the groups and suggested that this situation was due to the effect of colchicine on platelet functions ${ }^{24}$. In the study of Özer et al. investigating subclinical inflammation indicators in children with FMF, MPV was found to be significantly higher in asymptomatic FMF patients compared to the control group 8 . In the study of Ylldırım Çetin et al. investigating subclinical inflammation indicators in adult FMF patients, MPV was found to be significantly lower in FMF patients in the attack-free period compared to the healthy control group ${ }^{25}$. Our study revealed that in adult FMF patients, MPV in the inter-attack period is higher than the healthy control group in terms of age and gender. While this finding overlaps with some studies in the literature, it also contrasts with others. We think that this may be due to the criteria determined when selecting patients for studies in the literature. It was thought that the sensitivity and specificity level of $65 \%$ might be due to the fact that the control group included quite a few people compared to the patient group.

FMF and inflammation studies in the literature have been conducted to investigate new inflammation markers that can be used in the subclinical period. Özer et al. found that MPV was significantly higher in FMF patients in the inter-attack period compared to the control group, and found that MPV could be a candidate as an indicator of subclinical inflammation in FMF patients ${ }^{8}$. Çetin et al. investigated the importance of MPV as a subclinical inflammation marker and thought that low MPV could indicate subclinical inflammation in FMF patients in the inter-attack period ${ }^{26}$. Uslu et al. showed that the neutrophil-lymphocyte ratio, which can be reached with a complete blood count, such as MPV, was found to be higher in FMF patients in the attack-free period compared to the healthy control group, and this could be used as an indicator for subclinical inflammation ${ }^{27}$. In our study, MPV was found to be higher in FMF patients in the subclinical period compared to healthy controls, and it was also found to be correlated with disease severity. We think that the lack of correlation might be due to the unequal distribution of patients according to the severity of the disease. In our study, when FMF patients were categorized according to Pras severity scoring, it was shown that MPV in the subclinical period increased as the severity of the disease increased. In the post-hoc analysis, it was determined that this difference continued in the comparisons of the three groups. Our findings support that high MPV in the subclinical period is associated with more severe FMF.

The use of platelet indices as a marker of inflammation began with a study about 16 years ago. In their study, Milovanovic et al. Found that MPV increased during active rheumatoid $\operatorname{arthritis}^{28}$. After this study, many articles have been published investigating the roles and changes of platelet indices during inflammation, especially in recent years. In our study, although all platelet indices (PLT, MPV, PDW and PCT) were compared between the patient and control groups, it is striking that only MPV was found to be high in FMF patients in the subclinical period.According to our results, MPV has been found to be a reliable subclinical inflammation marker in adult patients with FMF. The risk of splenomegaly, heart diseases and especially amyloidosis increases with subclinical inflammation in FMF patients ${ }^{27-29}$. According to 
the results of our study, thanks to the closer follow-up of FMF patients with high MPV in the attack-free period, complications that are closely related to mortality can be detected earlier.

In conclusion, although the retrospective design of our study has some limitations, such as the small number of the control group, and the fact that platelet indices were not evaluated according to the genetic mutation types; we did not find any other study investigating disease severity and thrombocyte indices in adult FMF patients in our literature review. The fact that the relation of MPV with FMF complications has not been investigated can be considered as another limitation of our study. There is a need for prospective studies investigating the importance of MPV as a subclinical inflammation marker in FMF patients and it's relationship with the complications of FMF.

Ethics Committee Approval: The present study was approved by Afyonkarahisar Health Sciences University Faculty of Medicine Clinical Research Ethics Committee of Clinical Studies with dated 20.09.2019 and 302 decision number.

Conflict of Interest: No conflict of interest was declared by the authors.

Financial Disclosure: No financial disclosure was declared by the authors.

\section{REFERENCES}

1. Berkun Y, Padeh S, Reichman B, et al. A Single Testing of Serum Amyloid A Levels as a Tool for Diagnosis and Treatment Dilemmas in Familial Mediterranean Fever. Semin Arthritis Rheum. 2007; 37: 182-8.

2. Schwabe AD, Peters RS. Familial mediterranean fever in armenians analysis of 100 cases. Medicine (Baltimore). 1974; 53: 453-62.

3. Marmaralı A. Garip bir karın ağrısı sendromu. Türk Tıp Cem Mec. 1946; 12.
4. Debeljak M, Toplak N, Abazi N, et al. The carrier rate and spectrum of MEFV gene mutations in central and southeastern European populations. Clin Exp Rheumatol. 2015; 33 (6 Suppl 94): S19-23.

5. Booty MG, Chae JJ, Masters SL,et aI. Familial Mediterranean fever with a single MEFV mutation: where is the second hit? Arthritis Rheum. 2009 Jun; 60: 1851-61.

6. Samuels J, Aksentijevich I, Torosyan Y, et al. Familial Mediterranean fever at the millennium. Clinical spectrum, ancient mutations, and a survey of 100 American referrals to the National Institutes of Health. Medicine (Baltimore). 1998; 77: 268-97.

7. Örün E, Yalçınkaya F, Özkaya N, Akar N, Gökçe H. Ailevi akdeniz ateşi (FMF) hastalığında akut faz yanıtı ile tümör nekrozis faktör-alfa, interlökin-8 ve interlökin-6 düzeylerinin değerlendirilmesi. Ankara Üniversitesi Tıp Fakültesi Mecmuası. 2002; 55: 1237.

8. Özer S, Yılmaz R, Sönmezgöz E, et al. Simple markers for subclinical inflammation in patients with familial mediterranean fever. Med Sci Monit. 2015; 21: 298-303.

9. Kelesoglu FM, Aygun E, Okumus NK, et al. Evaluation of subclinical inflammation in familial Mediterranean fever patients: relations with mutation types and attack status: a retrospective study. Clin Rheumatol. 2016 Nov; 35: 2757-63.

10. Bulut $M$, Ceri $M$, Unverdi $S$, et al. Higher Pentraxin-3 Levels are Associated With Inflammation in Familial Mediterranean Fever. J Clin Lab Anal. 2016 Nov; 30: 978-81.

11. Ozturk K, Ekinci Z. Can serum amyloid a level be used to support the Familial Mediterranean Fever diagnosis? Pediatr Rheumatol. 2014; 12: 1-2.

12. Cemil BÇ, Ataş H. Psoriasis Hastalarında Biyolojik Tedavinin Sistemik İnflamatuvar Belirteçler ve Plateletcrit Üzerine Etkisi. Dicle Med J. 2016; 43: 477-83.

13. Göknar N, Küçükkoç M, Demir AD, Vehapoglu A, Öktem F. Çocukluk Çagi Nefrotik Sendromunda Ortalama Trombosit Hacminin Önemi/The Importance of Mean Platelet Volume in Children with Nephrotic Syndrome. Dicle Tip Derg. 2016; 43 : 275. 
14. Isik M, Sahin H, Huseyin E. New platelet indices as inflammatory parameters for patients with rheumatoid arthritis. Eur J Rheumatol. 2014; 1: 1446.

15. de Gaetano G, Cerletti C, Nanni-Costa MP, Poggi A. The blood platelet as an inflammatory cell. Eur Respir J Suppl. 1989 Jun; 6: 441s-445s.

16. Evangelista V, Celardo A, Dell'Elba G, et al. Platelet contribution to leukotriene production in inflammation: in vivo evidence in the rabbit. Thromb Haemost. 1999 Mar; 81: 442-8.

17. Ceresa IF, Noris P, Ambaglio C, Pecci A, Balduini CL. Thrombopoietin is not uniquely responsible for thrombocytosis in inflammatory disorders. Platelets. 2007 Dec; 18: 579-82.

18. Pras E, Livneh A, Balow JE, et al. Clinical differences between North African and Iraqi Jews with familial Mediterranean fever. Am J Med Genet. 1998; 75: 216-9.

19. Musabak U, Sengul A, Oktenli C, et al. Does immune activation continue during an attack-free period in familial Mediterranean fever? Clin Exp Immunol. 2004; 138: 526-33.

20. Bagci S, Toy B, Tuzun A, et al. Continuity of cytokine activation in patients with familial Mediterranean fever. Clin Rheumatol. 2004; 23: 333-7.

21. Erken E, Ozer HTE, Gunesacar R. Plasma interleukin-10 and interleukin-12 levels in patients with familial Mediterranean fever. Rheumatol Int. 2006; 26: 862-4.

22. Simsek I, Pay S, Pekel A, et al. Serum proinflammatory cytokines directing $\mathrm{T}$ helper 1 polarization in patients with familial Mediterranean fever. Rheumatol Int. 2007; 27: 807-11.

23. Coban E, Adanir H. Platelet activation in patients with Familial Mediterranean Fever. Platelets. 2008; 19: 405-8.

24. Abanonu GB, Daskin A, Akdogan MF, Uyar S, Demirtunc R. Mean platelet volume and $\beta$ thromboglobulin levels in familial mediterranean fever: Effect of colchicine use? Eur J Intern Med. 2012; 23: 661-4.

25. Yildirim Cetin G, Gul O, Kesici-Metin F, Gokalp İ, Sayarloglu M. Evaluation of the Mean Platelet Volume and Red Cell Distribution Width in FMF: Are They Related to Subclinical Inflammation or Not? Int J Chronic Dis. 2014; 2014: 1-5.

26. Cetin GY, Gul O, Kesici-Metin F, Gokalp I, Sayarlioglu M. THU0458 MPV and RDW: Subclinical Inflammation Markers in Attack-Free Familial Mediterranean Fever (FMF) Patients. Ann Rheum Dis. 2013; 72(Suppl 3): A319-A319.

27. Uslu AU, Deveci $\mathrm{K}$, Korkmaz $\mathrm{S}$, et al. Is neutrophil/lymphocyte ratio associated with subclinical inflammation and amyloidosis in patients with familial Mediterranean fever? Biomed Res Int. 2013; 2013: 185317.

28. Milovanovic $M$, Nilsson $E$, Järemo $P$. Relationships between platelets and inflammatory markers in rheumatoid arthritis. Clin Chim Acta. 2004 May; 343: 237-40.

29. Bilginer Y, Akpolat T, Ozen S. Renal amyloidosis in children. In: Pediatric Nephrology. 2011. p. 121527. 